\title{
Chapter 20 \\ Religious Tourism and Pilgrimages in the Central Portuguese Way to Santiago and the Issue of Accessibility
}

\author{
Maria Fátima Silva \\ Portucalense University, Portugal \\ Isabel Martins Borges \\ Portucalense University, Portugal
}

\begin{abstract}
With this chapter, the authors intend to present the objectives of the research project that they have been developing related to the issue of accessibility of religious tourism and pilgrimages in the Portuguese Way to Santiago. The geographic focus covers the area of the Central Way between Porto and Valença. The developed research enables them to present and reflect on important results. Regarding accessible tourism and accessibility to cultural heritage, especially religious architectural and accommodation sites, the authors conclude that there has been a minimum investment resulting in a manifest lack of accessibility. However, at other levels the impacts have been very positive resulting in a socio-cultural development of the populations of the geographic area under study: the number of places of accommodation have increased significantly and some of these places are renovated old buildings, rehabilitating and safeguarding the architectural heritage and the memory of localities.
\end{abstract}

\section{INTRODUCTION}

Tourism is considered one of the most important pillars for the sustainability of the territories, reaching a dynamic and an international dimension that place it in a prominent platform among the different economic activities. As it occurs in many other tourist destinations, also in Portugal, religious tourism presents itself as one of the growing segments, both as an economic activity and as a movement of people, being considered strategic.

DOI: $10.4018 / 978-1-5225-5730-2 . c h 020$ 
According to I. Dias (2010), the most visible relationship between tourism and religion lies in the substantial number of sacred buildings of relevant tourist interest and the intention of tourists to visit. Thus, religious tourism, which can be understood as an activity developed by citizens who travel for religious reasons or to participate in religious events, represents an interesting opportunity for the development of tourist activities. This type of traveller is more loyal to the visited tourist destination than the traditional tourist, repeating visits in a shorter period (Robles, 2001).

Although the concepts of religious tourism and pilgrimage tourism are very similar, and some authors even consider them to be the same, there are, however, some differences. In the case of religious tourism, the focus is on places of worship; regarding pilgrimage tourism, in addition to considering these places of worship, it emphasizes the connection among places, in a necessity of travel for the accomplishment of the visit, which causes the appearance of routes, itineraries or pilgrimage circuits (Gil de Arriba, 2006), among which is the Way of Santiago, one of the most recognized.

Portugal is a route of temples, cults and religious festivals and a point of passage to other places of worship, such as Santiago de Compostela. In addition, the Portuguese Pilgrimage Ways to Santiago de Compostela were included in the update of the Indicative List of Portugal to World Heritage, held in May 2016, which attests to its importance, particularly in the national structuring of this type of itinerary. The application for the integration of this asset was promoted by the Associação de Peregrinos Via Lusitana and the Associação Espaço Jacobeus. The primary purpose will be to develop and promote the international recognition of these itineraries in Portuguese soil and it includes the Caminho Central Português, the Caminho da Costa, the Caminho Interior Português, and the most recent Caminhos de Torres and Nascente.

In a particularly challenging time for the world, a substantial part of people finds in the pilgrimage to Santiago de Compostela a message of hope that comforts them. During the Middle Age, when the first pilgrimages arose, only devotees of all social classes, including royalty, visited it. Today we find all types of pilgrims, regardless the reasons, and a substantial percentage of walkers do not do it only for religious reasons but for cultural or other reasons.

Based on these assumptions, in this chapter, the authors seek essentially to address the socio-cultural impacts of religious tourism and pilgrimages to Santiago, studying with particular accuracy the section of the Portuguese (also known as medieval) Middle Way between Porto and Valença, highlighting the problems of accessibility, both the cultural heritage, especially the religious architectural that has a direct relationship with this itinerary, and the pilgrim hostels, namely public.

Among other aspects to be addressed, the chapter aims to meet the following objectives:

- Contextualize in cultural historical terms the Way of Santiago, namely the central, Portuguese or medieval, focusing on the section between Porto and Valença, with emphasis on the issue of accessible tourism;

- $\quad$ Analyse the statistical data of the Oficina del Peregrino in Santiago de Compostela, between 2004 and 2016;

- To make the survey, based on previously prepared records (religious architectural heritage, diverse heritage related to the ways, accessibility conditions to places of worship and museums, conditions of accessibility to accommodation sites), and its treatment and analysis;

- $\quad$ Reflect on the evolution of the lodging, regarding pilgrim hostels (official and private) and spaces of TER (Tourism in Rural Areas, in future publications), as well as the adaptation in terms of accessibility and rehabilitation of historic architectural spaces and its impact on the community; 
19 more pages are available in the full version of this document, which may

be purchased using the "Add to Cart" button on the product's webpage:

www.igi-global.com/chapter/religious-tourism-and-pilgrimages-in-the-central-

portuguese-way-to-santiago-and-the-issue-of-

accessibility/210797?camid=4v1

This title is available in Advances in Hospitality, Tourism, and the Services

Industry, InfoSci-Books, InfoSci-Business and Management, Business,

Administration, and Management, Communications, Social Science, and

Healthcare, InfoSci-Social Sciences and Humanities. Recommend this

product to your librarian:

www.igi-global.com/e-resources/library-recommendation/?id=132

\section{Related Content}

Analysis of the Contribution of ICT to Cultural and Religious Tourism: In Communicating Religious Heritage to Visitors and Tourists

Célia M. Q. Ramos and Ana Mafé-García (2019). Handbook of Research on Socio-Economic Impacts of

Religious Tourism and Pilgrimage (pp. 167-194).

www.igi-global.com/chapter/analysis-of-the-contribution-of-ict-to-cultural-and-religious-

tourism/210785?camid=4v1a

Religious Themes in Contemporary Art

Codrina Laura Ionita (2017). Multiculturalism and the Convergence of Faith and Practical Wisdom in

Modern Society (pp. 188-218).

www.igi-global.com/chapter/religious-themes-in-contemporary-art/173888?camid=4v1a

Religious Heritage and Nature: Spirit of Place and Tourism in a Brazilian Case

Isabela Barbosa Frederico and Pedro Paulo A. Funari (2019). Handbook of Research on Socio-Economic

Impacts of Religious Tourism and Pilgrimage (pp. 148-166).

www.igi-global.com/chapter/religious-heritage-and-nature/210784?camid=4v1a

Women and Religion in the Indian Diaspora

Annapurna Devi Pandey (2017). Multiculturalism and the Convergence of Faith and Practical Wisdom in

Modern Society (pp. 250-264).

www.igi-global.com/chapter/women-and-religion-in-the-indian-diaspora/173893?camid=4v1a 